\title{
Penggunaan Tetes Telinga Serum Autologous dengan Amnion untuk Penutupan Perforasi Membran Timpani
}

\author{
Hidayatul Fitria, Yan Edward
}

\section{Abstrak}

Latar Belakang: Gangguan pendengaran atau ketulian mempunyai dampak yang merugikan bagi penderita , keluarga, masyarakat maupun negara. Salah satu penyebab ketulian yang sering dijumpai adalah radang telinga tengah, terutama yang disertai perforasi membran timpani yang menetap. Penutupan perforasi membran timpani dapat dilakukan dengan operatif dan konservatif. Secara konservatif sudah banyak cara yang dilakukan. Salah satunya dengan mengkaustik tepi perforasi dengan menggunakan silver nitrat untuk membuat luka baru, kemudian digunakan amnion sebagai jembatan (bridge) dan faktor regulasi yang terdapat pada tetes telinga serum autologous. Tujuan: Untuk menjelaskan gambaran penggunaan amnion sebagai jembatan dan tetes telinga serum autologous sebagai faktor regulasi. Tinjauan pustaka: Penutupan perforasi membran timpani dapat dilakukan secara konservatif salah satunya dengan menggunakan tetes telinga serum autologous sebagai faktor regulator, amnion sebagai jembatan dan penggunaan silver nitrat pada tepi perforasi untuk membuat luka baru. Serum autologous memiliki asselerator pertumbuhan yaitu epidermal growth factor (EGF), transforming growth factor $\beta 1$ (TGF- $\beta 1$ ) dan fibronektin. Asselerator pertumbuhan ini dapat kita temukan pada penyembuhan membran timpani normal. Sedangkan membran amnion adalah jaringan semi transparan tipis yang membentuk lapisan terdalam membran fetus dengan susunan membran basalis yang tebal dan jaringan stroma avaskuler. Membran amnion mempercepat pembentukan epitel normal dengan menekan pembentukan jaringan fibrosis. Sel epitel amnion memproduksi faktor pertumbuhan seperti fibroblast growth factor dan transforming growth factor beta. Faktor pertumbuhan akan membantu komunikasi antara epitel dan sel fibroblast stroma untuk menekan proliferasi dan diferensiasi jaringan fibrosis. Kesimpulan: Diperlukan tiga elemen pada penutupan perforasi membran timpani yaitu faktor regulasi, jembatan (bridge) dan membuat luka baru pada tepi perforasi.

Kata kunci: tetes telinga serum autologous, membran amnion, perforasi membran timpani

\section{Abstract}

Background: Hearing loss or deafness have an adverse impact on patients, families, communities and the country. One cause of deafness that often met is middle ear inflammation, especially those with persistent tympanic membrane perforation. Closure of tympanic membrane perforation can be performed with operative and conservative. The conservatives have done with a lot of ways. One of them is cauterize edge of perforation by using silver nitrate to make a new wound, then used the amnion as a bridge and regulatory factors present in autologous serum eardrops. Objective: To describe the use of amnion as a bridge and autologous serum eardrops as a regulatory factor. Literature review: Closure of tympanic membrane perforation conservatively can be done either by using the autologous serum eardrops as a factor regulator, amnion as a bridge and the use of silver nitrate on the edge of the perforation to create a new wound. Autologous serum have asselator growth of Epidermal Growth Factor (EGF), Transforming Growth Factor $\beta 1$ (TGF- $\beta 1$ ) and fibronectin. Asselerator growth factor can be found on normal tympanic membrane healing. While the amniotic membrane is semi-transparant thin tissue that forms the deepest layer of fetal membranes with formation of a thick basement membrane and tissue stroma avaskuler. Amniotic membrane accelerate the formation of normal epithelial tissue by pressing the formation of fibrosis. Amniotic epithelial cells produce growth factors such as fibroblast growth factor and transforming growth factor beta. Growth factors will help the communication between epithelial and stromal fibroblast cells to suppress proliferation and differentiation of tissue fibrosis. Conclusion: It takes three elements on the closure of tympanic membrane perforation factor regulation, bridge and make new cuts on the edge of the perforation.

Keywords: autologous serum eardrops, amnion membrane, tympanic membrane perforation

Affiliasi penulis : Bagian Telinga Hidung Tenggorok Bedah Kepala Leher (THT-KL) Fakultas Kedokteran Universitas Andalas Padang. Korespondensi : Yan Edward, Bagian Telinga Hidung Tenggorok Bedah Kepala Leher (THT-KL) Fakultas Kedokteran Universitas Andalas Padang.dr.yanedward@gmail.com Telp: 0751-810900

\section{Pendahuluan}

Gangguan pendengaran atau ketulian mempunyai dampak yang merugikan bagi penderita, keluarga, masyarakat maupun negara. Penderita akan mengalami kesulitan dalam berkomunikasi dengan lingkungannya. Kehilangan kesempatan dalam aktualisasi diri, mengikuti pendidikan formal di sekolah 
umum, kehilangan kesempatan memperoleh pekerjaan, yang pada akhirnya berakibat pada rendahnya kualitas hidup yang bersangkutan.

Menurut perkiraan WHO (World Health Organization) pada tahun 1995 terdapat 120 juta penderita pendengaran di seluruh dunia. Jumlah tersebut mengalami peningkatan yang sangat bermakna pada tahun 2001 menjadi 250 juta orang; 222 juta diantaranya adalah penderita dewasa dengan sisanya (28 juta) adalah anak berusia di bawah 15 tahun. Dari jumlah tersebut kira-kira 2/3 diantaranya berada di negara berkembang. ${ }^{1}$

Jenis ketulian terdiri dari ketulian tipe konduktif, sensorineural dan campuran antara keduanya. Tuli konduktif terjadi apabila terdapat gangguan hantaran bunyi pada sistem konduksi di dalam telinga, termasuk di dalamnya bila terjadi perforasi membran timpani. Salah satu penyebab ketulian yang sering kita jumpai adalah radang telinga tengah, terutama yang disertai perforasi membran timpani yang menetap atau permanen. Keadaan ini dapat menyebabkan ketulian tipe konduktif pada berbagai tingkatan. Radang telinga tengah atau otitis media baik yang akut maupun kronis merupakan salah satu penyakit infeksi yang banyak terdapat di masyarakat kita. ${ }^{2}$ Pada pertemuan konsultasi WHOSEARO (South East Asia Regional Office) Interconutry Meeting (Colombo) disimpulkan bahwa pada negara dibawah koordinasi WHO SEARO penyebab gangguan pendengaran terbanyak adalah otitis media supuratif kronik (OMSK) dan di Indonesia diikuti oleh tuli kongenital, tuli akibat bising dan prebikusis. ${ }^{1}$

Perforasi membran timpani permanen adalah suatu lubang pada membran timpani yang tidak dapat menutup secara spontan dalam waktu tiga bulan setelah perforasi. Perforasi membran timpani dapat disebabkan karena trauma atau infeksi telinga tengah dan biasanya dapat menutup spontan kecuali bila perforasi besar atau terjadi infeksi kronik di telinga tengah maka perforasi akan permanen. ${ }^{2}$

Gladstone dkk (1995) memperkirakan prevalensi perforasi membran timpani sekitar 1-3\% pada populasi di Amerika Serikat. Prevalensi perforasi membran timpani akibat OMSK di negara berkembang berkisar antara 5-10\%, sedangkan di negara maju 0,5-2\%. Diperkirakan sekitar 10 juta penduduk Indonesia menderita OMSK. Survei Nasional Kesehatan Indera Penglihatan dan Pendengaran tahun 1994-1996 menunjukkan prevalensi OMSK antara 2,10-5,2\%. ${ }^{3,4}$ Frekuensi OMSK benigna di RS Dr Cipto Mangunkusumo Jakarta pada tahun 1989 sebesar $15,21 \%$ dari seluruh kunjungan. Di RS Hasan Sadikin Bandung dilaporkan frekuensi OMSK benigna selama periode $1988-1990$ sebesar $15,7 \%$ dan pada tahun 1991 dilaporkan prevalensi OMSK benigna sebesar 10,96\% dari seluruh kunjungan. Frekuensi penderita OMSK benigna di RS Dr Sardjito Yogyakarta pada tahun 1997 sebesar 8,2\%. Data catatan medis kunjungan kasus baru penderita OMSK benigna di RS Sardjito tahun 2002 adalah 460 orang, sedangkan jumlah seluruh kunjungan di poliklinik THT pada tahun tersebut adalah 13.524 orang, maka frekuensi OMSK benigna adalah 3,4\%. ${ }^{3}$ Data poliklinik THT RSUP $H$. Adam Malik Medan tahun 2006 menunjukkan pasien OMSK merupakan 26\% dari seluruh kunjungan pasien. $^{5}$

Sementara di RSUP Dr M Jamil jumlah kunjungan OMSK benigna tahun 2002 adalah 1.300 kunjungan. ${ }^{6}$
Beberapa keluhan yang dirasakan penderita perforasi membran timpani permanen antara lain penurunan ketajaman pendengaran, tinitus dan kekambuhan infeksi telinga tengah. Dengan demikian sudah semestinya dilakukan terapi untuk menutup perforasi membran timpani akibat OMSK benigna. Penutupan perforasi membran timpani dapat dilakukan dengan operatif dan konservatif. ${ }^{2}$ Teknik konservatif mengurangi biaya, minimal manipulasi, prosedur operasi relatif sederhana, mengurangi lama operasi, mengurangi biaya, dapat dilakukan sekaligus pada kedua telinga, mengurangi risiko operasi dan dapat dilakukan dengan rawat jalan. ${ }^{7,8}$ Usaha penutupan perforasi membran timpani permanen secara konservatif sudah lama dicoba, dengan cara seluruh tepi perforasi membran timpani permanen dibuat luka baru. ${ }^{2}$ Penggunaan bahan kaustik pertama kali diperkenalkan oleh Roosa tahun 1867 dengan memakai silver nitrat untuk membuat luka baru tepi perforasi dan trikloroasetat digunakan pertama kali tahun 1895. Kemudian dilakukan kombinasi kaustik dengan kertas sebagai jembatan memberikan hasil yang lebih baik. Berdasarkan hal ini Derlacki mempopulerkan teknik paper pacth. ${ }^{9,10}$ Cara konservatif ini memerlukan waktu lama, rerata waktu menutup 7 bulan 4 hari, sedangkan pembuatan luka baru harus diulang setiap dua minggu dan pada kertas penutup ditetesi larutan euthymol dua kali sehari sebanyak dua tetes. Angka keberhasilan mencapai $45 \%$ dari 131 perforasi membran timpani permanen. ${ }^{2}$

Membran amnion digunakan luas untuk tandur konjunktiva dan diduga dapat digunakan sebagai tandur untuk membran timpani. Pada penelitian yang dilakukan oleh Fouad dengan menggunakan tandur membran amnion yang dibandingkan dengan fasia temporalis untuk penutupan membran timpani tidak terdapat perbedaaan yang bermakna dalam penutupan perforasi membran timpani dan perbaikan air bone gap tetapi terdapat perbedaan yang bermakna dalam durasi operasi. Begitu juga dengan penelitian yang dilakukan oleh Harvinder tahun 2005 tidak terdapat perbedaan bermakna dalam penutupan perforasi membran timpani dan air bone gap. ${ }^{11}$

\section{ANATOMI DAN HISTOLOGI MEMBRAN TIMPANI}

\section{Anatomi membran timpani}

Membran timpani berbentuk hampir lonjong, terletak obliq di liang telinga, membatasi liang telinga dan kavum timpani. Diameter membran timpani ratarata sekitar $1 \mathrm{~cm}$, paling panjang pada arah anteriorinferior ke superior posterior. ${ }^{\$ 2}$ Membran timpani merupakan dinding lateral mesotimpani dan sebagian kecil epitimpani, memisahkan kavitas timpanika dengan liang telinga luar. Garis tengah posterosuperior ke antero-inferior 9-10 mm, sedangkan garis tengah tegak melalui manubrium mallei 8-10 mm. Sebagian besar tepi lingkarannya menebal dan terbentuk oleh jaringan fibrokartilago sebagai anulus timpanikus yang menempati sulkus timpanikus. Di batas superior sulkus timpanikus, anulus timpanikus menjadi jaringan fibrosa yang berjalan ke arah sentral sebagai plika maleolaris anterior dan posterior, membentang ke prosesus lateralis maleus. Daerah segitiga kecil di atas plika maleolaris, tidak mempunyai anulus timpanikus dikenal sebagai pars flasida atau membran shrapnell yang melekat langsung pada 
tulang petrosus, sedangkan sisanya yang lebih besar dan tegang adalah pars tensa. Bila dilihat dari liang telinga luar, pars tensa ini cekung dengan kecekungan maksimal pada ujung inferior manubrium mallei yang disebut juga sebagai umbo. ${ }^{2}$

\section{Histologi membran timpani}

Membran timpani mempunyai ketebalan 0,07-0,20 $\mathrm{mm}$ yang terdiri atas tiga lapis, yaitu (1) epitel skuamus kompleks merupakan lapisan paling luar sebagai lanjutan kulit liang telinga luar, (2) lamina propria yang merupakan jaringan fibrosa terletak di tengah, (3) lapisan mukosa yang merupakan lapisan terdalam sebagai lanjutan lapisan mukosa telinga tengah (gambar1).

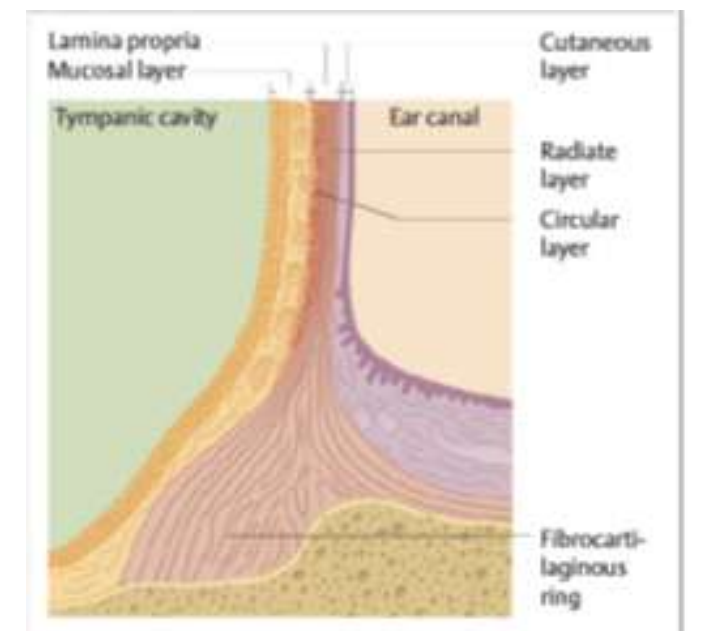

Gambar 1. Stuktur histologis membran timpani ${ }^{13}$

Epitel skuamus kompleks terdiri atas stratum korneum, stratum granulosum, stratum spinosum dan stratum basalis. Stratum korneum merupakan lapisan yang paling luar terdiri atas satu sampai enam lapis sel, berstruktur tanpa organela tetapi mempunyai membran dan dermosom. Stratum granulosum terdiri dari satu sampai tiga lapis sel yang tepinya rata dan mempunyai dermosom, kadang-kadang di antara tonofilamen terdapat granula keratohialin dan granula lamelar. Stratum spinosum terdiri atas dua sampai tiga lapis sel yang berisi tonofilamen, mitokondria dan ribosom. Stratum basalis merupakan lapisan epitel skuamus yang paling dalam yang terdiri atas satu lapis sel, dipisahkan dari lamina propria oleh membran basalis. Pada seluruh lapisan epitel skuamus tidak terdapat ujung serabut saraf dan granula melanin. ${ }^{2}$

Lamina propria terdiri dari jaringan fibrosa radier yang terletak di sebelah luar sedangkan lapisan jaringan ikat longgar yang mengandung fibroblas, makrofag, serabut syaraf dan kapiler terletak di antara jaringan fibrosa sirkuler dengan lapisan mukosa. Lamina propria juga mengandung sel Scwann dan akson yang berfungsi sebagai reseptor regangan. Serabut saraf dan kapiler tidak menembus membran basalis dan lapisan mukosa. Jaringan fibrosa radier dari lamina propria membungkus umbo. ${ }^{14}$ Lamina

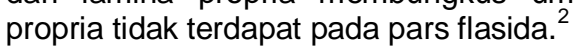

\section{Perdarahan dan persarafan membran timpani}

Pembuluh darah kapiler pada membran timpani berasal dari cabang-cabang pembuluh darah liang telinga luar dan kavitas timpanika yang saling dan terkonsentrasi dekat anulus timpanikus, manubrium mallei dan pars flasida. Persarafan sensoris bagian luar membran timpani, merupakan terusan dari persarafan sensoris kulit liang telinga. Nervus aurikulotemporalis mengurus bagian posterior dan inferior membran timpani, sedangkan bagian anterior dan superior diurus oleh cabang aurikularis nervus vagus. Persarafan sensoris permukaan dalam membran timpani diurus oleh nervus Jacobson yaitu cabang timpani nervus glosofaringeus. ${ }^{12}$

\section{OTITIS MEDIA SUPURATIF KRONIK}

\section{Definisi}

Otitis media supuratif kronik adalah peradangan akibat infeksi mukoperiosteum kavitas timpani yang ditandai oleh perforasi membran timpani dengan sekret yang keluar terus menerus atau hilang timbul dan dapat menyebabkan perubahan patologik yang permanen. ${ }^{3,5,15}$

Proctor pada tahun 1980 memberi batas waktu 6 minggu untuk terjadinya awal proses kronis pada OMSK sedang Paparela pada tahun 1983 mengatakan bahwa kronisitas cenderung berdasarkan kelainan patologis yang telah terjadi dan pada umumnya setelah peradangan berlangsung 12 minggu. ${ }^{2,3}$

OMSK secara klasik dapat dibagi menjadi dua golongan, yaitu otitis media supuratif kronik tipe benigna (OMSK benigna) atau tipe tubotimpanum atau tipe safe dan tipe maligna, atau tipe atikoantral atau tipe unsafe. Mawson membagi OMSK benigna menjadi OMSK benigna tipe aktif, tipe laten dan tipe inaktif. Pada OMSK benigna yang laten pada saat pemeriksaan kavum timpani kering setelah mendapatkan pengobatan, akan tetapi sebelumnya ada riwayat otore yang hilang timbul. Pada OMSK benigna inaktif bila didapatkan riwayat otore di masa lalu dan pada saat pemeriksaan kavum timpani kering tanpa kemungkinan kekambuhan dalam waktu dekat. Pada otitis media supuratif tipe benigna proses infeksi hanya terbatas pada mukosa telinga tengah saja dan bagian telinga tengah yang terkena adalah mesotimpanum dan hipotimpanum serta tuba auditoria. Tipe ini jarang menimbulkan komplikasi yang berbahaya. ${ }^{2}$

\section{Faktor predisposisi}

Faktor predisposisi kronisitas otitis media ini adalah (1) Disfungsi tuba auditoria kronik, fokal infeksi seperti sinusitis kronik, adenoiditis kronik dan tonsilitis kronik yang menyebabkan infeksi kronik atau berulang pada saluran nafas atas dan selanjutnya mengakibatkan udem serta obstruksi tuba auditoria. Beberapa kelainan seperti hipertrofi adenoid dan celah palatum menyebabkan fungsi tuba auditoria terganggu. Gangguan kronis fungsi tuba auditoria menyebabkan proses infeksi di telinga tengah menjadi kronis. (2) Perforasi membran timpani yang menetap menyebabkan mukosa telinga tengah selalu berhubungan dengan udara luar. Bakteri yang berasal dari kanalis auditorius eksternus atau dari luar lebih leluasa masuk ke dalam telinga tengah menyebabkan infeksi kronis pada mukosa telinga tengah. ${ }^{3}$ (3) Bakteri yang resisten terhadap antibiotika. Bakteri yang tersering diisolasi pada OMSK adalah Pseudomonas aeruginusa dan Staphylococcus aureus. Sebagian besar bakteri tersebut telah resisten terhadap antibiotika yang lazim dipergunakan. Ketidaktepatan atau terapi yang tidak adekuat menyebabkan kronisitas $^{\text {infeksi. }}{ }^{3}$ (4) Faktor konstitusi, alergi 
merupakan salah satu faktor konstitusi yang dapat menyebabkan kronisitas. Pada keadaan alergi ditemukan perubahan berupa bertambahnya sel goblet dan berkurangnya sel kolumner bersilia pada mukosa telinga tengah dan tuba auditoria sehingga produksi cairan mukoid bertambah dan efisiensi silia berkurang. ${ }^{3}$ Perubahan lain adalah udem mukosa tuba yang menyebabkan fungsi tuba auditoria terganggu. Faktor konstitusi lainnya adalah penurunan daya tahan tubuh. $^{2}$

Meskipun proses infeksi pada OMSK yang terjadi dapat diatasi dengan baik, akan tetapi gejala sisa yang terjadi berupa perforasi membran timpani yang menetap memerlukan tindakan lanjut pengobatan untuk penutupan perforasi secara konservatif maupun berupa pembedahan timpanoplasti. $^{2}$

\section{TETES TELINGA AUTOLOGOUS SERUM}

Penutupan membran timpani merupakan proses regenerasi. Untuk penyembuhan jaringan diperlukan tiga elemen yaitu sel, jembatan (bridge) dan faktor regulasi. Pada perforasi yang kecil telah digunakan lemak sebagai tandur dan teknik yang dipakai underlay dengan menggunakan fibrin glue.,16

Baru-baru ini penggunaan serum autologous dalam bentuk tetes air mata dikemukakan sebagai pengobatan baru untuk kelainan permukaan luar okuler yang berat. Serum tidak bersifat antigen, tetapi memiliki faktor pertumbuhan yang banyak, vitamin, imonoglobulin dan secara in vitro dan in vivo dapat menstimulasi proliferasi berbagai jaringan dalam penyembuhan luka. ${ }^{17,18,19,20,21}$ Pada penelitian yang dilakukan Tsubota $^{18}$ menemukan kontaminasi yang sangat rendah pada botol serum yang digunakan untuk pengobatan Sjogren's sindroma. Serum berisi antibakteri seperti lgG, lisozym, dan komplemen. Oleh karena itu tidak perlu penyimpanan yang lebih spesifik untuk serum ini agar terhindar dari efek samping yang tidak diinginkan. Kultur kuman serum autologous yang dilakukan Kakehata ${ }^{20}$ memberikan hasil negatif setelah 14 hari serum autologous diambil dan diencerkan dengan antibiotik tetes telinga.

Tetes telinga serum autologous didapatkan dengan mengambil darah vena kemudian disentrifus selama 5 menit dengan kecepatan $3000 \mathrm{rpm}$. Kemudian serum ini diencerkan $50 \%$ secara steril dengan antibiotik tetes telinga dan dimasukan dalam vial $5 \mathrm{cc}$. Autologous serum ears drop dapat disimpan dalam refrigerator pada suhu $4^{\circ} \mathrm{C}$ dan diambil saat dibutuhkan. $^{20}$ Tsubota $^{18}$ menyebutkan serum autologous dapat disimpan selama 1 bulan dalam refrigerator suhu $4^{\circ} \mathrm{C}$. Dalam frezzer suhu $-20^{\circ} \mathrm{C}$ dapat disimpan selama 3 bulan.

Tetes telinga serum autologous oleh Kakehata $^{20}$ digunakan untuk penutupan perforasi membran timpani dimana tetes telinga serum autologous berfungsi sebagai pelembab. Tepi perforasi dilukai dengan silver nitrat 10\% sampai memutih. Kemudian perforasi ditutup dengan membran chitin yang berfungsi sebagai jembatan. Tetes telinga serum autologous diteteskan 1-2 tetes pada liang telinga dan dibiarkan selama 10 menit. Hal ini dilakukan 2-4 kali sehari di rumah dan dievaluasi setiap 2 minggu. Penutupan perforasi membran timpani terjadi pada 11 telinga dari 19 telinga yang diterapi pada penelitian ini. Selama penggunaan serum autologous tidak ditemukan efek samping seperti nyeri, inflamasi dan hiperkeratosis.

\section{Faktor-faktor pertumbuhan dalam tetes telinga serum autologous}

Pada pemeriksaan chemiluminescent enzyme immunoassay pada serum didapatkan interleukin 6 (IL-6), epidermal growth factor (EGF) transforming growth factor $\beta 1$ (TGF- $\beta 1$ ) dan fibronektin yang diukur dengan enzyme-linked immunosorbent assay. ${ }^{19}$

Akselerator pertumbuhan ini dapat ditemukan pada penyembuhan membran timpani normal, menghasilkan proliferasi epitel dan migrasi dari daerah yang vaskularisasinya baik pada membran timpani yang dekat dengan annulus dan handle maleus menuju perforasi. Penyembuhan membran timpani melalui retraksi tepi perforasi dengan penutupan epitel sebelum lapisan jaringan ikat dan penutupan lapisan mukosa. Sudah banyak penelitian yang menggunakan akselerator pertumbuhan khususnya EGF. Penggunaan topikal EGF akan memberikan efek yang diinginkan. Lee dkk menggunakan secara topikal 25 $\mu \mathrm{g}$ dan $12,5 \mu \mathrm{g}$ EGF yang dioleskan pada gelfoam selang hari selama 6 hari. Dan didapatkan penutupan perforasi $80 \%$ dari telinga yang diobati dibandingkan dengan telinga kontrol. ${ }^{22}$

EGF adalah 54 amino-acid polipeptida yang menstimulasi pesan pada RNA, DNA dan sintesis protein pada berbagai jenis tipe sel, yang berperan dalam pertumbuhan sel epitel dan meningkatkan usia hidup sel. Juga menstimulasi pertumbuhan fibroblast dan neoangiogenesis jaringan. ${ }^{22}$

EGF telah digunakan secara lokal pada penyembuhan luka bakar dan ulkus diabetik pada tungkai. Efek positif pada defek yang persisten di epitel kornea manusia juga telah ditemukan. ${ }^{22}$

Reseptor EGF ditemukan pada membran timpani babi dengan afinitas yang tinggi dan mempercepat penyembuhan pada perforasi membran timpani akut pada kucing. Pada perforasi membran timpani kronik oleh Amoil dkk seperti dikutip oleh Ramsay juga sudah dilakukan pada percobaan terhadap binatang chinchilla. Tetapi pada penggunaan topikal EGF pada membran timpani manusia yang dilakukan oleh Ramsay tidak memperlihatkan efek yang diinginkan seperti pada percobaaan binatang. Ramsay tidak membuat luka baru pada tepi perforasi. Berdasarkan hal tersebut Ramsay ${ }^{22}$ berkesimpulan bahwa penutupan perforasi membran timpani tidak ditentukan oleh kosentrasi EGF dan lama pemakainya, mungkin dengan membuat luka baru pada tepi perforasi akan memperbaiki hasil.

Sommers melakukan penelitian immunohistokimia dari faktor-faktor pertumbuhan pada membran timpani yang perforasi. TGF- $\beta 1$ terdapat pada perforasi membran timpani kronik dalam lapisan jaringan ikat dan pada lapisan subepitelial dengan akumulasi TGF- $\beta 1$ mencolok pada tepi perforasi. $^{23}$

Penelitian imunohistokimia oleh Spandow dkk tentang karakteristik struktural perforasi membran timpani yang persisten pada 25 telinga manusia dewasa menunjukkan bahwa hialuronat, fibronektin dan glikosaminoglikan serta faktor pertumbuhan epidermis (epidermal growth factor) hanya sedikit ditemukan di sekitar tepi perforasi, hal ini menjadi alasan terhentinya proses penyembuhan untuk menutup perforasi membran timpani. ${ }^{2}$

Chauvin ${ }^{2}$ mendapatkan penutupan perforasi membran timpani dengan hanya menggunakan faktor- 
faktor pertumbuhan terjadi pada hari 21-23 pada penelitian menggunakan binatang marmot.

Kakehata ${ }^{20}$ menemukan aktifitas faktor pertumbuhan tetap stabil sampai 14 hari setelah pengenceran serum autologous dengan antibiotik walaupun kadarnya berkurang separoh.

\section{MEMBRAN AMNION}

\section{Struktur membran amnion}

Membran amnion adalah jaringan semi transparan tipis yang membentuk lapisan terdalam membran fetus, dengan susunan membran basalis yang tebal dan jaringan stroma avaskuler. ${ }^{21,24,25,26}$ Penggunaan membran amnion fetus pertama kali digunakan oleh Davis tahun 1910 untuk transplantasi kulit. ${ }^{11,24,27}$ Kemudian di bidang okuler De Rotth tahun 1940 pertama kali menggunakan membran amnion sebagai tandur pada rekonstruksi permukaan konjungtiva. ${ }^{24,25,28}$ Selanjutnya membran amnion banyak digunakan untuk pananganan luka bakar; penutupan luka; rekonstruksi pada rongga mulut, kandung kemih, dan vagina; timpanoplast; artroplasti. 24,29

Membran amnion berasal dari jaringan ekstra embrional terdiri dari komponen fetus (chorionic plate) dan komponen maternal (desidua). Komponen fetus termasuk membran amnion dan membran chorion, memisahkan fetus dengan endometrium. Membran amnion fetus pada kehamilan aterm terdiri atas dua lapisan utama. Lapisan terluar atau chorion berhubungan dengan sel-sel induk. Lapisan terdalam adalah membran amnion terdiri atas selapis sel epitel kuboid, membran basalis yang tebal dan stroma yang avaskuler (gambar 2). ${ }^{24,30}$

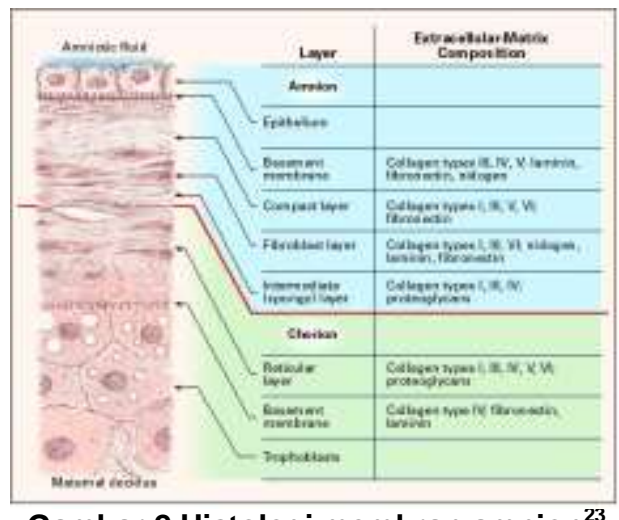

Gambar 2.Histologi membran amnion ${ }^{23}$

Ketebalan membran amnion antara 0,02-0,5 $\mathrm{nm}^{2}$ Membrana basalis merupakan salah satu membran tebal dalam tubuh manusia. Lapisan compact stroma menghubungkan membrana basalis dengan lapisan fibroblast. Kolagen pada lapisan compact dihasilkan oleh sel mesenkim yang berada pada lapisan fibroblast. Kolagen intersisial yaitu tipe I dan tipe III didapatkan lebih banyak dan berfungsi menjaga integritas mekanik dari membran amnion, serta berbentuk bundles parallel. Kolagen tipe $\mathrm{V}$ dan VI berbentuk filamen menghubungkan antara kolagen intersisial dengan membrana basalis epitel. Lapisan intersisial yaitu zona spongiosa yang berdekatan dengan membran chorion, berisi proteoglikan dan glikoprotein yang terlihat seperti spongy pada preparat histologi. $^{24}$

\section{Membran amnion non viable}

Membran amnion sebagai bahan transplantasi dapat berupa membran amnion yang masih hidup (viable) atau membran amnion yang sudah mati (non-viable). Membran amnion yang masih hidup dapat berupa membran amnion segar atau diawetkan dengan teknik hipotermi untuk penyimpanan jangka pendek (1 bulan) dan dengan teknik kriopreservasi untuk penyimpanan dalam jangka panjang ( 6 bulan). Membran amnion yang nonviable dicapai dengan teknik liofilisasi, gliserolisasi, denaturalisasi kimia, dan sterilisasi dengan radiasi sinar gama. ${ }^{2}$

Salah satu jenis membran amnion non-viable adalah membran amnion kering yang telah mengalami proses liofilisasi. Proses liofilisasi atau freeze drying menghilangkan kandungan air secara selektif melalui proses sublimasi menjadi bentuk es kemudian secara langsung mengalami proses penguapan tanpa melalui fase pencairan. Karakteristik dari materi yang telah mengalami proses freeze drying adalah bahan tersebut menjadi solid dan tidak dapat berinteraksi secara fisika atau kimiawi. Proses strerilisasi yang dilakukan pada bahan yang telah mengalami proses liofilisasi adalah dengan radiasi. Membran amnion yang telah mengalami proses liofilisasi ini sel epitelnya akan mati, namun sifat-sifat fisik seperti tegangan putus, daya tembus uap air dan daya serap air tidak terjadi perubahan, serta kandungan kimiawi yang ada seperti laminin, integrin, fibronektin dan kolagen yang dibutuhkan untuk proses reepitelisasi saat ditransplantasikan masih tetap dipertahankan. ${ }^{31}$

Peran fibronektin adalah untuk melengketkan sel ke berbagai matriks ekstraseluler. Fibronektin adalah dimer dari 2 peptida serupa. Setiap rantai panjang $60-70 \mathrm{~nm}$ dan tebal $2-3 \mathrm{~nm} .{ }^{31}$ Laminin merupakan glikoprotein yang berfungsi melengketkan sel. ${ }^{32}$

Membran amnion non-viable mudah didapatkan dan harga relatif murah serta dapat disimpan dalam jangka waktu lama. ${ }^{2}$

\section{Aplikasi penggunaan membran amnion}

Penelitian klinis mekanisme fisiologis membran amnion pada rekonstruksi kerusakan permukaan okuler didasarkan atas dua efek utama, yaitu fasilitasi epitelisasi dan penghambatan inflamasi dan fibrosis. Bagian dasar membran amnion merupakan substrat yang ideal untuk menunjang pertumbuhan sel progenitor epitel dengan memperpanjang kehidupan. Membran amnion mempercepat pembentukan epitel normal dengan menekan pembentukan jaringan fibrosis. ${ }^{24}$ Sel epitel amnion memproduksi faktor pertumbuhan seperti fibroblast growth factor dan transforming growth factor beta. $^{25}$ Faktor pertumbuhan tersebut mengatur proliferasi dan diferensiasi fibroblast stroma. ${ }^{24}$

Selain itu faktor pertumbuhan akan membantu komunikasi antara epitel dan sel fibroblast stroma untuk menekan proliferasi dan diferensiasi jaringan fibrosis. ${ }^{21}$ Pembentukan sel fibroblast stroma yang normal mendorong terjadinya epitelisasi yang normal. $^{2}$

Pada penelitian Sato yang menganalisis ekstrak membran amnion (segar dan diawetkan) dengan dan tanpa epitel membran amnion, mendapatkan ekstrak membran amnion yang diawetkan menunjukkan penurunan $50 \%$ kadar faktor pertumbuhan. ${ }^{2}$ 
Pada penelitian Koizumi yang menganalisis membran amnion yang diawetkan selama 1 bulan tanpa epitel membran amnion menunjukkan kandungan protein EGF, TGF- $\alpha, K G F, H G F$ dan TGF$\beta 1$, TGF- $\beta 2$. Pada membran amnion dengan epitel kadar faktor pertumbuhan tersebut di atas lebih banyak. $^{2}$

Pada penelitian yang dilakukan oleh Hartanto $^{2}$ keberhasilan penutupan perforasi membran timpani pada kelompok membran amnion sebanyak 27 subyek (75\%) dan pada kelompok kertas rokok sebanyak 18 subyek (50\%). Hartanto menggunakan membran amnion sebagai jembatan setelah tepi perforasi dibuat luka baru dengan trikloroasetat $10 \%$ dan dioleskan asam hialuronat $1 \%$.

Pada pemeriksaan histologis dengan pewarnaan Trichrome Masson didapatkan bahwa permukaan membran amnion mengandung laminin, kolagen tipe IV, V, integrin $\alpha 6$ dan $\beta 4$. Stroma amnion mengandung fibronektin dan integrin a5 dan $\beta 1$. Pada transplantasi membran amnion pada kasus kerusakan konjungtiva yang luas dan ekstensif dimana proses reepitelisasi tidak berjalan dengan baik maka komponen pada membran amnion diharapkan dapat menggantikan membran basalis konjungtiva yang rusak, karena membran basalis konjungtiva mempunyai komponen utama kolegen tipe IV dan V, laminin dan integrin. Transplantasi membran amnion akan mempercepat epitelisasi konjungtiva sehingga mencegah pembentukan fibrosis konjungtiva yang berlebihan. ${ }^{27}$

Aplikasi membran amnion kering untuk mempercepat proses penyembuhan luka telah dibuktikan dalam penelitian Dali dan Noer pada tahun 2001. Pada penelitian tersebut dibandingkan antara membran amnion dengan tulle (pembalut kasa yang bersifat tidak melekat dan mengandung antibiotik chlorhexidine) dalam proses penyembuhan luka. Proses epitelisasi pada luka superfisial lebih cepat dan lebih tebal secara bermakna pada luka yang ditutupi dengan membran amnion dibandingkan dengan luka yang ditutupi dengan tulle. Penelitian oleh Saputro dan Noer pada tahun 2002 yang membandingkan perawatan luka bakar derajat 2 superfisial di RSUD Dr. Soetomo Surabaya, pemakaian membran amnion lebih baik dibandingkan dengan pemakaian tulle dalam hal kecepatan penyembuhan luka, kurangnya rasa sakit saat perawatan luka dan dalam hal pencegahan infeksi pemakaian membran amnion sama baiknya dengan pemakaian tulle. Lapisan epitel pada kulit kanalis auditorius eksternus bagian dalam memiliki persamaan dengan lapisan epitel pada permukaan lateral membran timpani, yaitu epitel skuamus kompleks dengan keratinisasi. ${ }^{2}$

Terdapat sembilan fungsi biologik yang spesifik dan keuntungan membran amnion sebagai penutup luka, yaitu:

(1) menurunkan jumlah bakteri pada luka, (2) mengurangi kehilangan cairan, (3) mempercepat penyembuhan luka, (4) melindungi pertumbuhan epitel, (5) menguatkan perlekatan dari permukaan luka, meningkatkan mobilitas dan menghilangkan rasa sakit, (6) mempersiapkan tandur jaringan, (7) persiapan pada defek kulit untuk menutup, (8) menurunkan stres fisiologis pada pasien, (9) stimulasi neovaskularisasi. ${ }^{2,24}$

Membran amnion mempunyai karakteristik yang baik untuk transplantasi di permukaan okuler dan kulit oleh karena tidak menampakkan human leucocyte antigen sehingga rejeksi imunologis tidak perlu dikhawatirkan dan membran amnion mempunyai kemampuan mencegah infiltrasi sel radang sehingga resiko infeksi pasca operasi lebih kecil. ${ }^{10,25,31,33,34,35}$ Disamping itu membran amnion juga mempunyai berbagai macam proteinase inhibitor seperti a1antikimotripsin, $\alpha 2$-makroglobulin, $\alpha 1$ antitripsin, $\alpha 2$ antiplasmin,inter- $\alpha 1$-tripsin inhibitor. ${ }^{25,31}$

Pemilihan membran amnion sebagai bahan jembatan (bridge) berdasarkan beberapa pertimbangan bahwa jaringan epitel dan stroma amnion mengandung faktor pertumbuhan sebagai fasilitator epitelisasi, yaitu epidermal growth factor (EGF), transforming growth factor $\alpha$ (TGF- $\alpha$ ), keratinocyte growth factor (KGF) dan basic fibroblast growth factor (bFGF), transforming growth factor $\beta$ 1-2 (TGF- $\beta 1-2)$. Stroma amnion mengandung komponen kolagen tipe IV, laminin, integrin 6 dan 4 yang merupakan komponen matriks ekstraseluler sebagai bahan penyusun membran basalis epitel sehingga mempercepat proses epitelisasi. Membran amnion yang telah diawetkan selama satu bulan masih mengandung faktor-faktor pertumbuhan tersebut, hal ini dibuktikan dengan metode pemeriksaan polymerase chain reaction $(P C R)$ maupun metode pemeriksaan ELISA. ${ }^{23,30}$

Chauvin $^{21}$ mendapatkan penutupan perforasi membran timpani dengan hanya menggunakan faktorfaktor pertumbuhan didapatkan bahwa perubahan penutupan perforasi terjadi pada hari 21 - 23 pada penelitian binatang marmot.

\section{FAKTOR-FAKTOR YANG MEMPENGARUHI PENUTUPAN PERFORASI MEMBRAN TIMPANI}

Untuk menstimulasi terjadinya regenerasi jaringan diperlukan manipulasi sel, jembatan dan faktor regulasi. ${ }^{19}$

Pada proses penutupan perforasi membran timpani pertama kali tertutup oleh epitel skuamus selanjutnya lamina propria dan lapisan mukosa, tertutup antara hari kelima sampai hari kesepuluh tergantung ukuran perforasi. Setelah hari keempat belas, ketiga lapisan tersebut terutama lapisan epitel skuamus kompleks ketebalannya berkurang, kembali ke bentuk membran timpani normal. Pada perforasi yang besar, proses pertumbuhan akan tetap berlangsung hanya bila pertumbuhan lamina propria mengikuti proliferasi epitel skuamus untuk membentuk substratum migrasi epitel. ${ }^{2}$

Kakehata $^{20}$ dkk melaporkan penggunaan kombinasi antara kauterisasi kimia untuk proliferasi sel, membran chytin sebagai jembatan dan tetes telinga autologous serum sebagai faktor regulasi. Mereka menggunakan silvernitrat untuk kauterisasi, tepi perforasi untuk munculnya proliferasi sel sebagai pengganti pembuatan luka baru. Sehingga hal ini dapat dilakukan pada pasien rawat jalan dan sifat invasifnya sedikit. Tandur bertindak sebagai jembatan untuk migrasi epitel skuamosa permukaan luar membran timpani dan mukosa dari permukaan dalam. $^{36}$

Beberapa faktor perlu diperhatikan dalam keberhasilan penutupan perforasi membran timpani permanen. Faktor pertumbuhan yang memacu pertumbuhan pembuluh darah baru mempunyai potensi mempercepat penyembuhan luka jaringan ikat. Ada empat macam faktor pertumbuhan yang bersifat angiogenik, yaitu fibroblast growth factor (FGF), 
transforming growth factor beta (TGF- $\beta$ ), plateletderived growth factor (PDGF) dan epidermal growth factor (EGF). ${ }^{24,25}$

Faktor angiogenik merangsang terbentuknya sel-sel endotelial vaskuler secara langsung atau tidak langsung. Secara langsung merangsang migrasi dan proliferasi sel endotelial vaskuler dengan mengikat reseptor spesifik permukaan membran sel endotelial, sedangkan secara tidak langsung melalui mediator makrofag. ${ }^{2}$

Setiap faktor angiogenik mempunya beberapa target sel. Target sel EGF, yaitu epitel, fibroblast dan endotel pembuluh darah. Pada ketiga lapisan membran timpani terutama sel epitel skuamus terdapat reseptor EGF.22 Untuk memperoleh efek $E G F$, target sel harus terpapar EGF paling sedikit lima jam. Karenanya diperlukan aplikasi berulang agar diperoleh hasil yang maksimal dan juga mempersingkat waktu penyembuhan sampai $30 \%{ }^{2}$ Hasil penelitian secara in vivo pada kucing menunjukkan EGF akan mempercepat penutupan perforasi membran timpani. ${ }^{22}$

Kekeringan tepi perforasi akan segera membunuh fibroblast muda dan memungkinkan pertumbuhan epitel skuamus yang terus berlangsung di bawah krusta yang kering sehingga epitel tersebut tumbuh melampaui tepi perforasi, bertemu dengan lapisan mukosa membran timpani. Dengan demikian proses penutupan membran timpani akan berhenti. ${ }^{17,21}$ Tetes telinga serum autologous berfungsi sebagai pelembab, disamping mempunyai faktor-faktor pertumbuhan. $^{20}$ Epitel skuamus kompleks cenderung tumbuh lebih cepat dibanding jaringan ikat dibawahnya sehingga akan bertemu dengan lapisan mukosa kecuali ada bahan tipis dan datar yang menempel pada seluruh permukaan tepi perforasi. ${ }^{2}$

Reaksi inflamasi yang akan merangsang pertumbuhan membran timpani. Keadaan ini didukung dari hasil penelitian pada guinea pig dengan cara membuat perforasi berukuran $2 \times 3 \mathrm{~mm}$ pada kuadran posterosuperior dan akhirnya berkesimpulan bahwa perforasi atau suatu luka baru akan mempertinggi aktivitas proliferasi pusat pertumbuhan sampai dua kali lipat dibandingkan keadaan normal. Pembuatan luka baru juga ditunjukan untuk memutuskan mucocutaneus junction di tepi perforasi yang menghalangi pertumbuhan epitel skuamus komplek ke arah yang benar. ${ }^{2}$

Faktor lain yang berpengaruh dalam proses penutupan perforasi membran timpani adalah infeksi tepi perforasi, luas perforasi, proses degenerasi atau timpanosklerosis di membran timpani, fungsi tuba auditoria, umur dan status gizi. Adanya infeksi di telinga tengah dan di tepi perforasi akan menghambat proses penyembuhan atau penutupan perforasi. Luas perforasi membran timpani berpengaruh karena semakin luas perforasi akan menyebabkan semakin banyak pusat-pusat pertumbuhan yang hilang. ${ }^{9}$ Hartanto pada penelitiannya melakukan penutupan perforasi membran timpani yang luas perforasinya tidak lebih $50 \%{ }^{2}$ Adanya proses degenerasi atau timpanosklerosis di membran timpani akan menghambat proses penutupan perforasi. Gangguan pada fungsi tuba auditoria akan menimbulkan retraksi membran timpani yang akan mengganggu proses penutupan perforasi membran timpani.

Umur berpengaruh dalam proses penyembuhan luka jaringan. Hal ini berkaitan dengan penurunan kapasitas proliferasi fibroblast dengan bertambahnya umur. Status gizi berpengaruh dalam proses penyembuhan luka jaringan secara umum karena berkaitan dengan faktor nutrisi untuk pembentukan jaringan baru. ${ }^{2}$

\section{KESIMPULAN}

1. Gangguan pendengaran atau ketulian mempunyai dampak yang merugikan bagi penderita, keluarga, masyarakat maupun negara.

2. Salah satu penyebab ketulian yang sering dijumpai adalah radang telinga tengah, terutama yang disertai perforasi membran timpani yang menetap

3. Penutupan perforasi membran timpani dapat dilakukan secara konservatif dan operatif

4. Penutupan membran timpani secara konservatif memiliki beberapa keuntungan biaya relatif lebih murah, manipulasi minimal, prosedur operasi relatif sederhana, mengurangi lama operasi, dapat dilakukan sekaligus pada kedua telinga, mengurangi risiko operasi dan dapat dilakukan dengan rawat jalan.

5. Salah satu cara penutupan perforasi membran timpani secara konservatif dengan menggunakan autologous serum ear drops dan membran amnion

6. Autologeus serum ear drop adalah diambil dari darah vena, kemudian disentrifus selama 5 menit dengan 3000 rpm dan berfungsi sebagai faktor regulator.

7. Membran amnion adalah jaringan semi transparan tipis yang membentuk lapisan terdalam membran fetus dengan susunan membran basalis yang tebal dan jaringan stroma avaskuler. Membran amnion mempercepat pembentukan epitel normal dengan menekan pembentukan jaringan fibrosis, berperan sebagai jembatan.

\section{DAFTAR PUSTAKA}

1. Suwento R. Standar Pelayanan Indera Pendengaran di Puskesmas. Komite Nasional Gangguan Pendengaran dan Ketulian 2007.

2. Hartanto D. Daya klinis membran amnion sebagai bahan bridge pada penutupan perforasi membran timpani secara konservatif. Tesis. Universitas Gajah Mada; 2004. 26-40.

3. Utami TE. Rinitis alergi sebagai factor risiko Otitis Media Supuratif Kronis. Cermin Dunia Kedokteran 2010;179. p. 425-29

4. Farida dkk. Alergi sebagai Faktor Risiko Terhadap Kejadian Otitis Media Supuratif Kronik tipe benigna. Jurnal Medika Nusantara. 2004;25(1):1-4

5. Aboet. Radang Telinga Tengah Menahun. Pidato Pengukuhan Jabatan Guru Besar Tetap dalam bidang IImu Kesehatan Telinga Tenggorok Bedah Kepala Leher pada Fakultas Kedokteran Universitas Sumatera Utara. Medan: 2007. p 2-26

6. Data Poliklinik Rawat Jalan Bagian THT-KL RSUP Dr M Djamil Padang. 2010

7. Dursun E dkk. Comparison of paper patch, fat and perichondrium myringoplasty in repair of small tympanic membrane perforations. 
Otolaryngology-Head and Neck Surgery 2008;138:353-356

8. Jones RO. Myringoplasty. In: Habermann RS. Middle ear and mastoid surgery.New York:Thieme; 2004.p 5-11

9. Spiros M. Closure o Tympanic Membrane. In Sambaugh. Surgery of the ear. Spain: Decker; 2003.p.400-20

10. Paparella. Mastoidectomy and tympanoplasty. In: Paparella dkk Otolaryngology. Philadelpia:WB Saunders Campany;1991.p.1405-1440

11. Fouad T. Utilization of amniotic membrane graft for repair of the tympanic membrane perforations. Ejentas Egyptian Journal of the ear, nose,throat; 2010. 31-35

12. Helmi. Otitis Media supuratif kronik. Jakarta:Balai penerbit Universitas Indonesia;2005: 4-75

13. Probts R. Middle ear. In: Probst dkk. Basic otolaryngology. Jerman: Thieme; 2006.p 22754

14. Huttenbrink. Biomechanical of Middle ear reconstruction. In: Jahnke $\mathrm{K}$. Middle ear surgery. Jerman: Thieme; 2000. P.24-47

15. Rahman S. Bacterial and Fungal study of suppurative otitis media with antibiotic susceptibility of the isolates. Dissertation.Bangalore;department of microbiology:2006. p.1-116

16. Sakagami et all. Simple underlay myringoplasty. The journal of laryngology \& otology. 2007;121: 840-44

17. Spandow dkk. Comparison of the repair of permanent tympanic membrane perforations by hydrocolloidal dressing and paper patch. The journal of laryngology and otology. 1995; 119: 1041-47

18. Tsubota K. et al. Treatment of dry eye by autologous serum application in Sjongren syndrome. Br J Ophthalmol; 1999; 83.390397

19. Geerling et al. Autologous Serum eye drops for ocular Surface Disorders. Br.J.Ophtalmol; 2004: (88) 1467-74

20. Kakehata et al. Autologous Serum Ear drops therapy with a chitin membrane for closing tympanic membrane perforations. Otology \& neorootology; 2008: (29) 791-95

21. Chauvin et al. Healing Large Tympanic Membrane Perforations Using Hyaluronic acid, basic fibroblat growth Factor and epidermal Growth factor. OtolaryngologyHead and neck Surgry; 1999: 43-48

22. Ramsay dkk. Effect of epidermal Growth factor on Tympanic Membranes with Chronis perforations: A clinical trial. OtolaryngologyHead and Neck surgery; 1995: 375-80

23. Kaftan et al. Topical application of transforming growth factor- $\beta$ in acute traumatic tympanic membrane perforations: in experimental study in rats. Wound Rep. Reg; 2006: (14) 453-56

24. Niknejad $\mathrm{H}$ et al. Properties of the amniotic membrane for potential use in tissue engineering. European Cell and materials; 2008: 15: 88-99

25. Tseng SCG. Amniotic Membrane Transplantation for Ocular surface reconstruction. Bioscience report; 2001:21: 481-90

26. Sippel KC. Amniotic membrane Surgery. Curr.opin.ophtalmol. 2002;12 (4):269-81

27. Letko et al. Amniotic Membrane Inlay and overlay grafting for Corneal ephitelial Defects and Stroma Ulcers. Arch Ophtalmol; 2001: 659-63

28. Schwann DL. Human Amniotic Membrane Transplantation for the Treatment of Ocular Surface Disease. Northeast Florida Medical journal. 2002;1: 1-3

29. Dua HS \& Blanco AA. Amniotic membrane transplantation. Br J Ophtalmol. 1999;83:748 52

30. Russo R et al. Polymormonuclear leucocyt Migration through human amnion membrane. The Journal of cell biology; 459-67

31. Libera RD et al. Assesment of the use of cryopreserved $X$ freeze-dried amniotic membrane for reconstruction of ocular surface in rabit model. Arq. Reras.Ophtalmol; 2008: 669-73

32. Kurpakus MW. Laminin-5 is a component of preserved amniotic membrane. Current Eye Research. 2001; 22: 353-57

33. Jae SK dkk. Amniotic membrane transplantation in infectious corneal ulcer. Cornea; 2001:720-26

34. Harvinder $S$ et al. Underlay Myringoplasty: Comparison of Human Amniotic Membrane to Temporalis Fascia Graft. Med. J Malaysia. 2005;60: 285-89

35. Mermet I et al. Use of amniotic membrane Transplantation in the Treatment Venous Leg Ulcers. Wound Rep.Reg. 2007; 15:459-64

36. Shinta FB, Taufiq SB. Angka Keberhasilan Miringoplasti pada perforasi membran timpani kecil, besar dan subtotal pada bulan Juni 2003 sampai Juni 2004. THT-KL FK Unpad/Perjan RS Hasan Sadikin Bandung. Avaliable: http/www.pustaka unpad etc.id. 